\title{
Field Measurement of PV Array Temperature for Tracking and Concentrating 1 k W penerators Installed in Malaysia
}

\author{
M. Effendy Ya'acob, ${ }^{1}$ H. Hizam, ${ }^{1,2}$ M. Amran M. Radzi, ${ }^{1,2}$ and M. Z. A. A. Kadir ${ }^{1,2}$ \\ ${ }^{1}$ Department of Electrical \& Electronic Engineering, Faculty of Engineering, Universiti Putra, 43400 Serdang, Selangor, Malaysia \\ ${ }^{2}$ Centre of Advanced Power and Energy Research (CAPER), Universiti Putra, 43400 Serdang, Selangor, Malaysia
}

Correspondence should be addressed to M. Effendy Ya’acob; fendyupm@gmail.com

Received 9 April 2013; Revised 5 September 2013; Accepted 7 October 2013

Academic Editor: Chun-Sheng Jiang

Copyright (C) 2013 M. Effendy Ya'acob et al. This is an open access article distributed under the Creative Commons Attribution License, which permits unrestricted use, distribution, and reproduction in any medium, provided the original work is properly cited.

\begin{abstract}
The effect of temperature elements for PV array with tracking and concentrating features installed in the tropical ground condition is presented. The temperature segment covers ambient temperature and surface and bottom temperature for three types of PV generator systems, namely, Fixed Flat (FF), Tracking Flat (TF), and Concentrating PV (CPV) generators. The location of measuring the cell temperature, $T_{\mathrm{c}}$ for the PV module is still being debated by researchers with the issue of how much the cell temperature ( $T_{\mathrm{c}}$ ) is being affected by the surface temperature $\left(T_{\mathrm{s}}\right)$, bottom temperature $\left(T_{\mathrm{b}}\right)$, and surrounding temperature $\left(T_{\mathrm{a}}\right)$ furthermore when it is located in fluctuating weather conditions. In this study, $\Delta T$ is calculated based on the difference between surface temperature and bottom-side temperaturewhichever the highest recorded at site for different kinds of PV generator systems but using the same CEEG $95 \mathrm{~W}$ monocrystalline PV module. The study embraces the direct correlation of various temperature elements in tropicalbased condition with $\Delta T$ values of $2.19^{\circ} \mathrm{C}$ for FF module, $2.22^{\circ} \mathrm{C}$ for TF module, and $2.72^{\circ} \mathrm{C}$ for $\mathrm{CPV}$ module. These values which reflect the different unique configurations are further analyzed using multiple linear regression (MLR) and analysis of variance (ANOVA) test for $T_{\text {array }}$ models. This study supports the continuous research in adapting PV technology for Malaysia.
\end{abstract}

\section{Introduction}

Energy generation via photovoltaic technology and application has been the most economical viable green resources, especially in tropical-based countries [1-7]. Based on ground condition of the tropics with fluctuating environmental weather condition, temperature element is a crucial factor to be determined based on standard testing condition (STC) and nominal operating cell temperature (NOCT) equations.

Electricity generation is one of the biggest energy sectors utilizing a lot of fossil fuels as the main supply, and this contributes significantly to the emission of greenhouse gas (GHG) that pollutes the environment. Because of this adverse effect on the environment, the government of Malaysia under the Ministry of Energy, Green Technology and Water has introduced Green Technology initiatives to promote this technology application in the country. Malaysia which is located near the equator naturally has an abundance of sunshine which produces solar radiation. Although Malaysia enjoys a uniform temperature throughout the year, it is, however, extremely rare to have a full day with completely clear sky in various seasons even in periods of severe drought. On the average, Malaysia receives about 6 hours of direct sunshine per day where it is seasonal, and spatial variations are thus very much the same as in the case of sunshine [8-12].

Maximum radiation received during a sunny day produces peak power $\left(\mathrm{W}_{\mathrm{p}}\right)$, where $90 \%$ of the extraterrestrial radiation becomes direct radiation, while the rest is being deflected as diffuse radiation [5].

This research intends to explore the effect of various temperature factors which correlates directly to the ground radiation level and crystalline PV energy generation. Two segments of temperature have been classified which are surface and bottom temperatures for three types of PV generator systems, namely, Fixed Flat (FF), Tracking Flat (TF), and Concentrating (CPV). The solar PV pilot plant with rated capacity of $10 \mathrm{~kW}$ is monitored, recorded, and analysed in real 
time via solar PV monitoring system (SPMS) using LabVIEW programming embedded in Compact Reconfigurable Input Output (cRIO) platform for system integration. The data have been collected for the duration of thirty consecutive days in June 2012.

1.1. Harvesting Energy from the Sun. Harvesting energy from the sun is a zero-carbon energy production activity where the sun reflects a solar fusion reactor emitting huge power of 63.11 MW. For every square metre surface the earth receives approximately $3.9 \times 10^{24} \mathrm{~J}$ which is equivalent to $1.08 \times 10^{18} \mathrm{kWh}$ of solar energy annually [13]. This figure is about ten thousand times more than the annual global primary energy demand and much more than all available energy reserves on earth. Solar energy can be subdivided in two forms which are the direct and the indirect solar energy sources. Technical systems using direct solar energy convert incoming solar radiation directly into useful energy application for instance heat and electricity. Natural process systems using indirect solar energy convert solar energy into other types of energy before coming to the user application for instance, wind, river, and plant growth.

Baños et al. [14] define solar energy as radiant energy that is produced by the sun where in many parts of the world, direct solar radiation is considered to be one of the best prospective sources of energy. Direct solar energy applications are usually based on the building design and concept where an active design converts solar energy into electricity or heat by means of solar energy conversion system and contrarily a passive design utilizes the light energy from the sun for artificial lighting and heating. Based on MS IEC 61836:2010 [15], the photovoltaic panels are defined as PV modules which are mechanically integrated, preassembled, and electrically interconnected whereas photovoltaic system is assembly of components that produce and supply electricity by the conversion of solar energy.

Generally, a photovoltaic solar cell consists of twolayer semiconductor material which, in nonradiated condition, behaves like a diode whose I-V curve is traditionally described by the equation $I_{D}=I_{0}\left(\exp \left(q V_{D} / n k T\right)-1\right)-$ $I_{L}$ where $I_{0}$ is the reverse saturation current or leakage current of the diode, $I_{L}$ is the light generated current or the photocurrent, $V_{D}$ is the voltage accross diode is the reverse saturation current of the diode, $q$ the electron charge $(1.602 \times$ $\left.10^{-19} \mathrm{C}\right), k$ the Boltzmann constant $\left(1.381 \times 10^{-23} \mathrm{~J} / \mathrm{K}\right)$, and $T$ the junction temperature which depends on the kind of the semiconductor used [16].

Around the globe, research on photovoltaic cell and processing technologies are focusing on new approach to reduce cost via reducing the number of processing steps with high consideration of overall performance and efficiency [17]. Photovoltaic conversion can be defined as the direct conversion of pure energy sunlight into electricity without any heat engine to interfere as described by Parida et al. in [18]. Photovoltaic devices are rugged and simple in design requiring very little maintenance, and their biggest advantage is their construction as portable standalone systems to give outputs from microwatts to megawatts. MS IEC 61836:2010 defines PV conversion efficiency as ratio of maximum PV output to the product of PV device area and incident irradiance measured under specified test conditions usually at standard testing condition (STC).

1.2. Temperature Factor in PV Cell Equation. Skoplaki and Palyvos [19] explain the effect of temperature rise in the PV cell as the thermally excited electron begins to dominate the electrical properties of the semiconductor bands. Wu et al. [20] further supported the temperature rise effect towards PV energy performance due to losses created when lattice vibrations interfere with the free passing of charge carriers and the junction begins to lose its power to separate charges and proposes temperature-dependent charge controller devise for effective solution.

The importance and effect of radiation toward the energy generation in Oman have been studied by Gastli and Charabi [21] with the application of GIS-based solar radiation map. Power conversion efficiency and overall output power of the solar cells change with temperature and solar irradiance level, and this statement is further supported via conducting field study for four different types of solar panels in real performance under tropical weather condition.

A significant positive correlation between PV module temperature and spectral irradiance distribution parameter by means of energy production has been proven by Minemoto et al. [22] in which both parameters were characterized using contour plots. The influence of module temperature variations towards the energy efficiency which can be described using contour graph created from statistical analysis method based on average photon energy (APE) and field output factor (FOF) of the silicon PV Module has been analysed by Nagae et al. [23]. This technique also proves that temperature rise really affects the PV module performance ratio $(\mathrm{PR})$ by producing contour graph for the temperature impact towards single-crystalline and amorphous silicon modules [24].

Skoplaki and Palyvos [25] found that there are other forms of heat energy transfer besides internal processes taking place within the semiconductor material during its bombardment by photons where convection mechanism in front and back sides of PV module panels plus heat conduction through mounting frames should be included in defining the energy balance. Park et al. [26] conducted a study to prove that there are such significant effects of the PV module's thermal characteristics on its electrical generation performance building-integrated photovoltaic (BIPV) where approximately $0.5 \%$ reduction of energy generated based on $1^{\circ} \mathrm{C}$ increase of the module temperature. This statement is supported by Kim et al. [27] where they emphasize that through a proper method of cooling PV module by means of heat dissipation process using fins, interestingly, the energy efficiency from a common PV module usually falls at a rate of $0.5 \% /{ }^{\circ} \mathrm{C}$ and it can be increased due to the drop in surface temperature especially on the highest heated portions of PV cell and ribbon where all means of cooling approach comes into the picture. 
The effect of temperature in PV system can be practically calculated based on cell temperature $\left(T_{c}\right)$ of each PV module. Nevertheless, the location of measuring $T_{\mathrm{c}}$ in the PV module is still being debated by researchers $[16,28,29]$ with the issue of how much the cell temperature $\left(T_{c}\right)$ is being affected by the surface temperature $\left(T_{\mathrm{s}}\right)$, bottom temperature $\left(T_{\mathrm{b}}\right)$, and surrounding temperature $\left(T_{\mathrm{a}}\right)$. An in-depth review on the PV module temperature by Iyengar et al. [17] highlighted a constant value of $k$ known as Ross coefficient as described in (1) based on simple expression of (2):

$$
\begin{gathered}
T_{\mathrm{c}}=T_{\mathrm{a}}+k G_{T}, \\
T_{\mathrm{c}}=T_{\mathrm{b}}+\frac{G_{T}}{G_{\text {ref }}} \Delta T .
\end{gathered}
$$

Ross coefficient, $k$, is derived by the ratio $\Delta T / \Delta G$ where $\Delta T$ is the difference between cell temperature $\left(T_{c}\right)$ and ambient temperature $\left(T_{\mathrm{a}}\right)$, and in this case it represents seven types of PV arrays commonly applied. The values of $T_{\mathrm{c}}$ have also been investigated by several studies [30-33] as follows:

$$
\begin{gathered}
T_{\mathrm{c}}=T_{\mathrm{a}}+0.035 G_{T}, \\
T_{\mathrm{c}}=T_{\mathrm{a}}+0.028 G_{T}-1, \\
T_{\mathrm{c}}=T_{\mathrm{a}}+0.031 G_{T}, \\
T_{\mathrm{c}}=T_{\mathrm{a}}+0.031 G_{T}-0.058 .
\end{gathered}
$$

In this study, the value of $\Delta T$ are calculated based on the difference between surface temperature and bottom-side temperature whichever the highest recorded at site and the value is suggested to be $3^{\circ} \mathrm{C}$ [17]. Highest temperature value is chosen to be the benchmark of $\Delta T$ mainly because of the PV performance degradation due to increase in temperature as described earlier. The value is derived based on average daily data in the month of June 2012 for different kinds of PV generator system but using the same CEEG $95 \mathrm{~W}$ monocrystalline PV module. This study embraces the justification of direct correlation of various temperature elements in tropical-based ground condition with a specified $\Delta T$ value for Fixed Flat, Tracking Flat, and Concentrating PV modules purposely to support the continuous research in adapting green resources of Solar PV in Malaysia. Statistical analysis of multiple linear regression (MLR) and the analysis of variance (ANOVA) are further applied to develop mathematical modelling for $T_{\text {array }}$ equations.

\section{Experimental Procedures}

Three types of PV generator systems with a rated (at STC) capacity of $1 \mathrm{~kW}$ each with the total sum energy of $10 \mathrm{~kW}_{\mathrm{p}}$ have been successfully configured in the Universiti Putra Malaysia (UPM), Serdang, Malaysia, at GPS coordinate of $2^{\circ} 59^{\prime} 20^{\prime \prime} \mathrm{N}: 101^{\circ} 43^{\prime} 30^{\prime \prime} \mathrm{E}$ as illustrated in Figure 1. The PV system is equipped with precalibrated temperature sensors, one solar-radiation sensor and one wind-speed sensor. The temperature sensors are for measuring the ambient temperature (sensor located close to the PV arrays), the PV cell face temperature, and the PV cell bottom temperature.

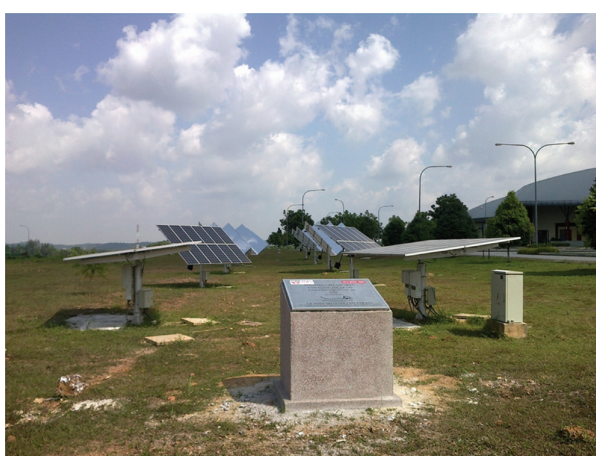

FIGURE 1: PV generator system configuration at site comprising CPV, Tracking Flat, and Fixed Flat arrays.

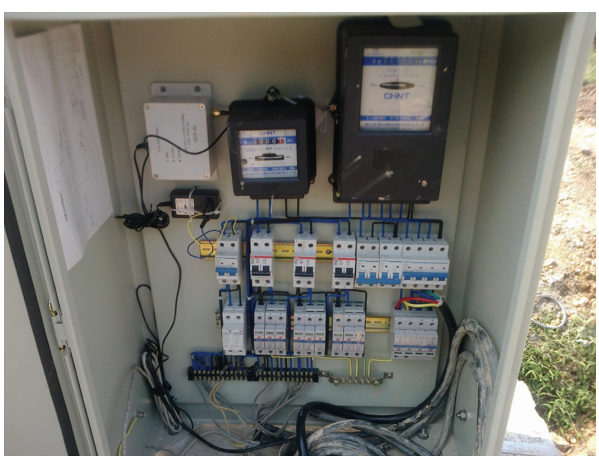

FIgURE 2: Arrangement of distribution box for DC and AC breakers connecting to the data logger and UPM Electricity Grid (Feeder Pillar).

The system is directly connected to UPM electrical distribution line via Feeder Pillar (FP) which links to the main switch board (MSB) as shown in Figure 2. Grid-connected system ensures full capacity generation with assumption of the highest generator efficiency during the operation period compared to a standalone system which has some limitations. The ten units of PV generator are connected to three units of Aurora inverter system with the capacity of $2 \times 3.6 \mathrm{~kW}$ and $6.0 \mathrm{~kW}$ for the purpose of Grid-tied operation.

The build-up areas for all PV generators are the same including the type of crystalline PV module used which is $3.6 \mathrm{~m}(\mathrm{~L}) \times 2.4 \mathrm{~m}(\mathrm{~W}) \times 2.8 \mathrm{~m}(\mathrm{H})$ with surface area of $8.64 \mathrm{~m}^{2}$. The differences between the 3 systems are quantity of PV module either 6 units or 12 units, tracking mechanism for $360^{\circ}$ rotation (dual-axis), and concentrating mirror. The open-circuit voltage $\left(V_{\mathrm{oc}}\right)$ for TF and $\mathrm{FF}$ is $270 V_{\mathrm{dc}}$, while $\mathrm{CPV}$ generates $135 V_{\mathrm{dc}}$. The short-circuit current $\left(I_{\mathrm{sc}}\right)$ for all $\mathrm{PV}$ arrays is the same which is $5.56 A_{\mathrm{dc}}$.

Field evaluation and comparison of the temperature effect are verified via installation of 10 units of type-K thermocouple sensor at the surface and bottom side of each PV generator system. The other temperature elements of internal inverter temperature and surrounding temperature are taken directly from the weather station and Aurora inverter internal temperature sensor link to solar PV monitoring system (SPMS) as illustrated in Figure 3. 


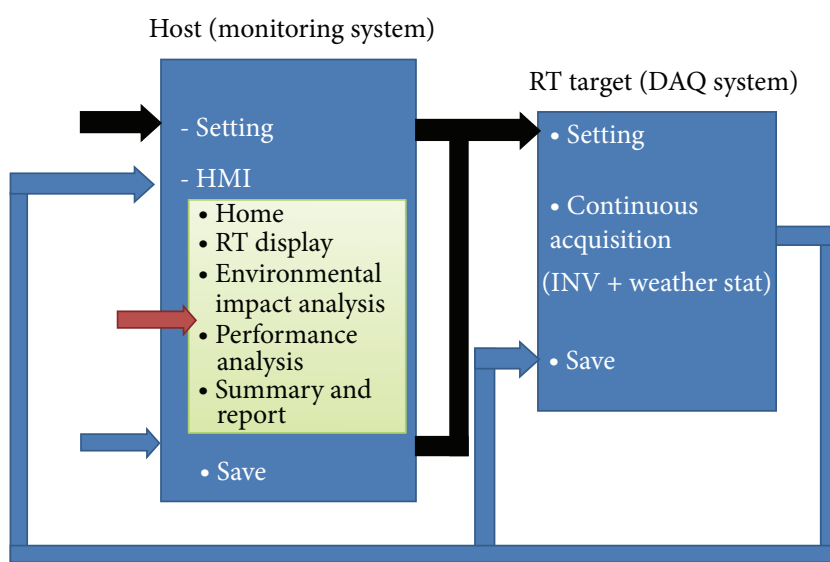

$\Rightarrow$ Sys. config.
$\Rightarrow$ Data
$\Rightarrow$ User input

FIGURE 3: Data flow in Solar PV Monitoring Station (SPMS).

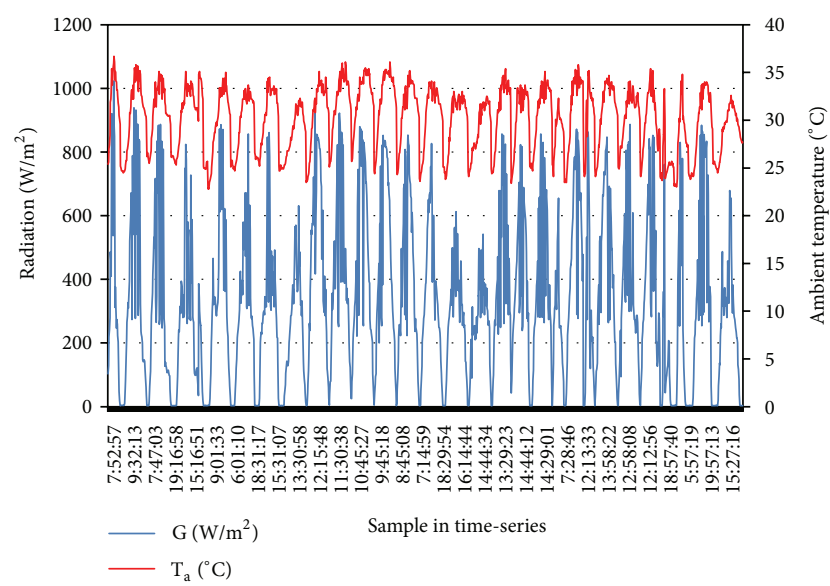

Figure 4: Correlation between sun radiation $\left(\mathrm{W} / \mathrm{m}^{2}\right)$ and ambient temperature $\left({ }^{\circ} \mathrm{C}\right)$ in time-series dependence for tropical condition at site.

To achieve the research objective of investigating correlations of real-time and synchronize mode between temperature elements in PV system application, the data logging and monitoring process are done using NI compact RIO device (cRIO) platform with preembedded combination of LabVIEW programming to represent the overall system flow. The monitoring process is done continuously throughout the duration of 30 days in the month of June 2012 and the data for radiation $(G)$ and ambient temperature $\left(T_{\mathrm{a}}\right)$ are described in Figure 4. The sample data is taken for the whole 30 days by 15 -minute interval so as to show fluctuating pattern at a specific time of the day.

The fluctuation pattern of radiation, $G$, ranges from $3 \mathrm{~W} / \mathrm{m}^{2}$ at $4.30 \mathrm{AM}$ up to $1023 \mathrm{~W} / \mathrm{m}^{2}$ at $2 \mathrm{PM}$ which is the highest value in the month. On the other hand, ambient temperature fluctuates at the value of $22.8^{\circ} \mathrm{C}$ up to $36.7^{\circ} \mathrm{C}$. The
TABLE 1: Sample of average daily data for surface and bottom temperature for different PV generator systems.

\begin{tabular}{lccccc}
\hline $\mathrm{FF}_{\mathrm{s}}\left({ }^{\circ} \mathrm{C}\right)$ & $\mathrm{FF}_{\mathrm{b}}\left({ }^{\circ} \mathrm{C}\right)$ & $\mathrm{TF}_{\mathrm{s}}\left({ }^{\circ} \mathrm{C}\right)$ & $\mathrm{TF}_{\mathrm{b}}\left({ }^{\circ} \mathrm{C}\right)$ & $\mathrm{CPV}_{\mathrm{s}}\left({ }^{\circ} \mathrm{C}\right)$ & $\mathrm{CPV}_{\mathrm{b}}\left({ }^{\circ} \mathrm{C}\right)$ \\
\hline 38.68 & 40.67 & 40.82 & 44.43 & 52.01 & 49.76 \\
38.29 & 40.8 & 40.96 & 43.8 & 51.67 & 49.21 \\
36.99 & 38.83 & 39.37 & 41.47 & 46.84 & 44.91 \\
40.09 & 41.69 & 43.53 & 46.79 & 56.2 & 53.54 \\
35.49 & 37.52 & 37.49 & 39.27 & 42.96 & 41.4 \\
33.95 & 35.25 & 34.79 & 36.07 & 38.83 & 37.56 \\
37.42 & 39.58 & 41.07 & 43.19 & 50.8 & 48.45 \\
36.65 & 38.75 & 39.44 & 41.65 & 47.73 & 45.78 \\
30.65 & 31.08 & 31.76 & 32.28 & 33.26 & 33.3 \\
37.49 & 39.69 & 40.65 & 42.61 & 49.15 & 46.99 \\
36.22 & 38.81 & 38.89 & 41.15 & 48.54 & 46.1 \\
36.33 & 38.37 & 39.27 & 41.89 & 49.74 & 46.89 \\
31.94 & 33.61 & 33.89 & 36 & 40.8 & 38.86 \\
36.22 & 38.46 & 38.35 & 42.23 & 50.26 & 42.7 \\
37.13 & 39.57 & 40.98 & 43.1 & 51.87 & 49.07 \\
34.53 & 36.25 & 35.77 & 37 & 39.98 & 38.49 \\
\hline
\end{tabular}

sun hours calculated for the whole month are 240 hours with $200 \mathrm{~W} / \mathrm{m}^{2}$ as the minimum sun radiation reference.

\section{Results and Discussion}

Sample data showing correlations between surface, bottom and ambient temperature is illustrated in Figure 5 with 700 samples of one-minute intervals.

The measured data for all temperature elements in this study is plotted with respect to radiation level at site as shown in Figure 6.

Based on Figure 6, the maximum value recorded for each temperature elements is $54^{\circ} \mathrm{C}$ for surface temperature, $48^{\circ} \mathrm{C}$ for bottom temperature, and $33.3^{\circ} \mathrm{C}$ for ambient temperature at the same time interval. The overall comparison of temperature elements for all 3 types of PV generator systems is described in Table 1 for average daily data with the highest temperature value comes from surface temperature of $\mathrm{CPV}$ generator.

For all the three types of PV generators, the surface and bottom temperatures fluctuate in the range from $30^{\circ} \mathrm{C}$ to $60^{\circ} \mathrm{C}$ which is an important value to determine cell or module temperature. For CPV generator, the surface temperature is much higher than the bottom value due to the mirror concentrating effect of heat convection. The surrounding or ambient temperature fluctuates in the range from $25^{\circ} \mathrm{C}$ to $33^{\circ} \mathrm{C}$ which reflects the nominal operating cell temperature (NOCT) in MS/IEC Standards with an average daily value of $29.56^{\circ} \mathrm{C}$.

Based on the average daily data analysis, the relationship between surface temperature $\left(T_{\mathrm{s}}\right)$ and the bottom temperature $\left(T_{\mathrm{b}}\right)$ are described in Table 2. 
TABLE 2: Relationship between temperature effects towards 3 types of PV generator systems.

\begin{tabular}{lll}
\hline & Temperature effect & Comments \\
$\begin{array}{l}\text { Fixed Flat PV } \\
\text { generator }\end{array}$ & $\begin{array}{l}\Delta T=2.19^{\circ} \mathrm{C} \\
\text { Surface temperature }\left(T_{\mathrm{s}}\right) \text { is lower by the AE value of } \\
5.63 \% \text { compared to the bottom temperature }\left(T_{\mathrm{b}}\right)\end{array}$ & $\begin{array}{l}\text { Most researchers adapt the bottom-side values as the } \\
\text { cell/module temperature for crystalline PV due to the } \\
\text { higher temperature value }\end{array}$ \\
\hline \multirow{2}{*}{$\begin{array}{l}\text { Tracking Flat } \\
\text { PV generator }\end{array}$} & $\begin{array}{l}\Delta T=2.22^{\circ} \mathrm{C} \\
\text { Surface temperature }\left(T_{\mathrm{s}}\right) \text { is lower by the AE value of } \\
5.4 \% \text { compared to the bottom temperature }\left(T_{\mathrm{b}}\right)\end{array}$ & $\begin{array}{l}\text { The same concept as above. The tracking mechanism which } \\
\text { receives peak radiation level most of the time results in } \\
\text { higher bottom temperature values compared to FF } \\
\text { generator }\end{array}$ \\
\hline \multirow{2}{*}{ CPV generator } & $\begin{array}{l}\Delta T=2.72^{\circ} \mathrm{C} \\
\text { Surface temperature }\left(T_{\mathrm{s}}\right) \text { is higher by the AE value of } \\
5.8 \% \text { compared to the bottom-side temperature }\left(T_{\mathrm{b}}\right)\end{array}$ & $\begin{array}{l}\text { The uniqueness of adapting two elements of tracking } \\
\text { mechanism and mirror concentrator creates much higher } \\
\text { value on the surface side of the PV module which } \\
\text { contradicts the normal concept of } T_{\mathrm{c}}\end{array}$ \\
\hline
\end{tabular}

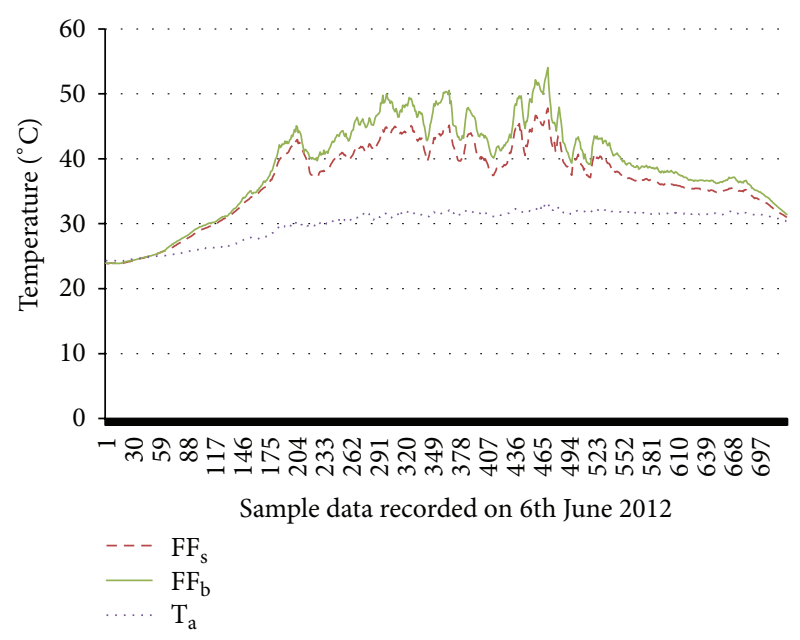

FIGURE 5: Correlation between ambient, surface, and bottom temperatures recorded on June 6, 2012.

Furthermore, based on MLR and ANOVA test, PV array temperature model with respect to the radiation and ambient temperature is described as follows:

For FF array,

$$
\begin{aligned}
T_{\text {array }}(\mathrm{FF})= & -0.117^{*} T_{\mathrm{a}}+0.002^{*} G \\
& +1.189^{*} \mathrm{FF}_{\mathrm{s}} \quad\left(R^{2}=0.975, \mathrm{SE}=0.444\right) .
\end{aligned}
$$

For TF array,

$$
\begin{aligned}
T_{\text {array }}(\mathrm{TF})= & 0.356^{*} T_{\mathrm{a}}-0.007^{*} G \\
& +1.08^{*} \mathrm{TF}_{\mathrm{s}} \quad\left(R^{2}=0.946, \mathrm{SE}=0.885\right) .
\end{aligned}
$$

For CPV array,

$$
\begin{aligned}
T_{\text {array }}(\mathrm{CPV})= & 0.233^{*} T_{\mathrm{a}}-0.006^{*} G \\
& +1.053^{*} \mathrm{CPV}_{\mathrm{b}} \quad\left(R^{2}=0.956, \mathrm{SE}=1.417\right)
\end{aligned}
$$

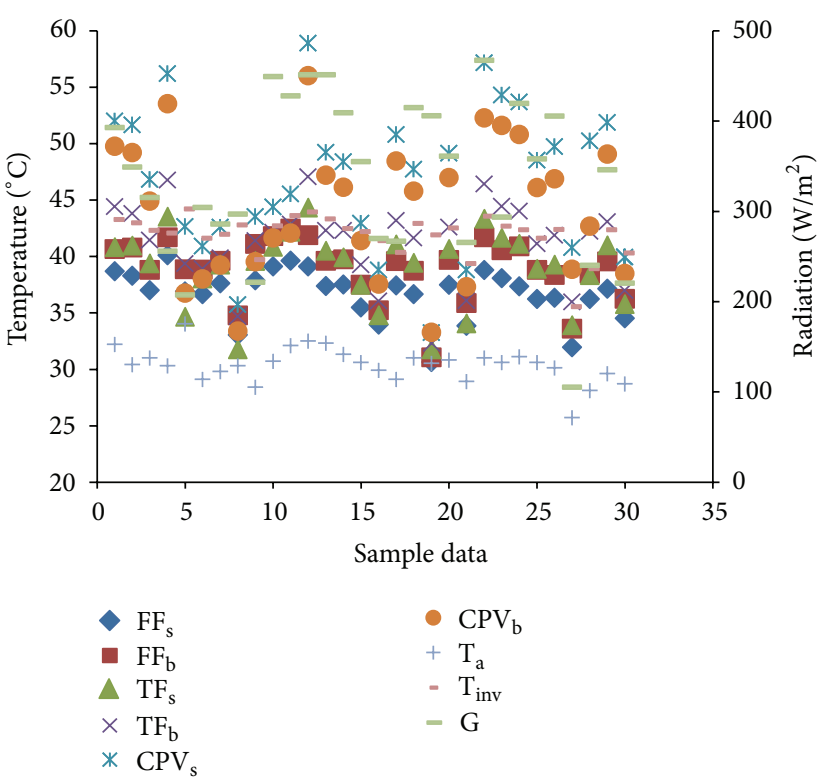

Figure 6: Plotted data for measured temperature elements with radiation levels in June 2012.

From the plotted data in Figure 6, an interesting temperature correlation can be obtained for internal inverter temperature $\left(T_{\text {inv }}\right)$ as folllow

$$
T_{\text {inv }}=0.867^{*} T_{\mathrm{a}}-0.005^{*} G \quad\left(R^{2}=0.875, \mathrm{SE}=0.65\right) .
$$

The linear regression model in (4) to (7) shows fairly strong correlation of the temperature elements with the tropical conditions of radiation and ambient temperature.

\section{Conclusion}

Review and field analysis on correlation between four temperature elements are presented. It was concluded that all temperature elements discussed have significant contribution either direct or indirect influences which affect the performance of photovoltaic generator system in providing sufficient energy supply. It is a known fact that PV conversion process does produce heat as energy wastage and PV module 
TABLE 3: CEEG PV module specification.

\begin{tabular}{lc}
\hline Electrical typical data & CEEG CSUN 95W-36M \\
\hline$P_{\text {mpp }}[\mathrm{W}]$ & 95 \\
$V_{\text {oc }}[\mathrm{V}]$ & 22.5 \\
$I_{\text {sc }}[\mathrm{A}]$ & 5.56 \\
$V_{\text {mpp }}[\mathrm{V}]$ & 18.3 \\
$I_{\text {mpp }}[\mathrm{A}]$ & 5.21 \\
Practical module efficiency & $17.05 \%$ \\
Voltage temperature coefficients & $-0.307 \% / \mathrm{K}$ \\
Current temperature coefficients & $+0.039 \% / \mathrm{K}$ \\
Power temperature coefficients & $-0.423 \% / \mathrm{K}$ \\
Series fuse rating [A] & 10 \\
Cells $4 \times 9$ @ 36 pieces & $125 \mathrm{~mm} \times 125 \mathrm{~mm}$ \\
monocrystalline solar cells series & \\
strings & with 2 bypass diodes \\
Junction box & length $600 \mathrm{~mm}, 1 \times 4 \mathrm{~mm}{ }^{2}$ \\
Cable & White toughened safety glass, \\
Front glass & $3.2 \mathrm{~mm}$ \\
Cell encapsulation & EVA (Ethylene-Vinyl-Acetate $)$ \\
Back sheet & composite film \\
Frame & Anodised aluminium profile \\
Dimensions & $1211 \times 546 \times 35 \mathrm{~mm}$ \\
Maximum surface load capacity & $2,400 \mathrm{~Pa})$ \\
Hail & Maximum diameter of $25 \mathrm{~mm}$ \\
Temperature range & $-40^{\circ} \mathrm{C}$ to $+85^{\circ} \mathrm{C}$ \\
\hline & \\
&
\end{tabular}

TABle 4: (a) Summary output (FF). (b) and (c) ANOVA.

(a)

\begin{tabular}{lc}
\hline \multicolumn{2}{c}{ Regression statistics } \\
\hline Multiple $R$ & 0.987429459 \\
$R$ Square & 0.975016936 \\
Adjusted $R$ Square & 0.972134275 \\
Standard error & 0.444029697 \\
Observations & 30 \\
\hline
\end{tabular}

(b)

\begin{tabular}{lccccc}
\hline \multicolumn{1}{c}{$d f$} & SS & MS & $F$ & Significance $F$ \\
\hline Regression & 3 & 200.0616483 & 66.68722 & 338.235 & $6.10857 E-21$ \\
Residual & 26 & 5.126221676 & 0.197162 & & \\
\hline Total & 29 & 205.18787 & & & \\
\hline
\end{tabular}

(c)

\begin{tabular}{lcc}
\hline & Coefficients & Standard error \\
\hline Intercept & -1.678085319 & 2.015645509 \\
$T_{\mathrm{a}}$ & -0.117136967 & 0.071238145 \\
Radiation $(G)$ & 0.001492943 & 0.001202588 \\
$\mathrm{FF}_{\mathrm{s}}$ & 1.188748497 & 0.04219168 \\
\hline
\end{tabular}

TABle 5: (a) Summary output (TF). (b) and (c) ANOVA.

(a)

\begin{tabular}{lcc}
\hline \multicolumn{2}{c}{ Regression statistics } \\
\hline Multiple $R$ & & 0.97275466 \\
$R$ Square & 0.946251629 \\
Adjusted $R$ Square & 0.940049894 \\
Standard error & 0.885232775 \\
Observations & 30 \\
\hline
\end{tabular}

(b)

\begin{tabular}{lccccr}
\hline & $d f$ & SS & MS & $F$ & Significance $F$ \\
\hline Regression & 3 & 358.698573 & 119.5662 & 152.5785 & $1.2743 E-16$ \\
Residual & 26 & 20.37456371 & 0.783637 & & \\
\hline Total & 29 & 379.0731367 & & & \\
\hline
\end{tabular}

(c)

\begin{tabular}{lcc}
\hline & Coefficients & Standard error \\
\hline Intercept & -9.503340876 & 4.063070816 \\
$T_{\mathrm{a}}$ & 0.356280226 & 0.135307719 \\
Radiation $(G)$ & -0.006620823 & 0.002569022 \\
$\mathrm{TF}_{\mathrm{s}}$ & 1.080144819 & 0.056718604 \\
\hline
\end{tabular}

TABLE 6: (a) Summary output (CPV). (b) and (c) ANOVA.

(a)

\begin{tabular}{lcc}
\hline \multicolumn{2}{c}{ Regression statistics } \\
\hline Multiple $R$ & & 0.977883672 \\
$R$ Square & 0.956256475 \\
Adjusted $R$ Square & 0.951209145 \\
Standard error & 1.417568074 \\
Observations & 30 \\
\hline
\end{tabular}

(b)

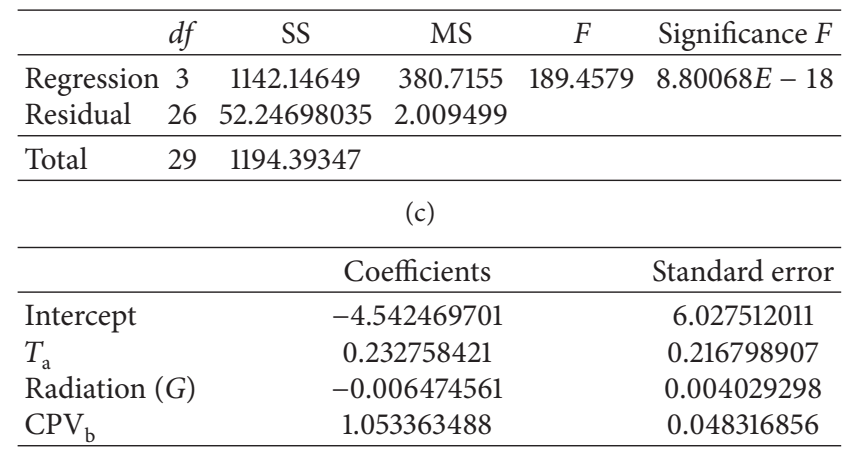

efficiency degrades with the increase in temperature which usually falls at a rate of $0.5 \% /{ }^{\circ} \mathrm{C}$. The highest $\Delta T$ value comes from the CPV array with the surface side producing higher heat energy. This study shares some findings of linearly correlated $T_{\text {array }}$ model with respect to radiation and ambient temperature for three types of uniquely configurated PV arrays installed in the tropics.

\section{Appendix}

See Table 3 .

MLR and ANOVA Test. See Tables 4, 5, 6, and 7. 
TABle 7: (a) Summary output ( $\left.T_{\text {inv }}\right)$. (b) and (c) ANOVA.

(a)

\begin{tabular}{lcc}
\hline \multicolumn{2}{c}{ Regression statistics } \\
\hline Multiple $R$ & & 0.934929786 \\
$R$ Square & 0.874093704 \\
Adjusted $R$ Square & 0.864767312 \\
Standard error & 0.650565694 \\
Observations & 30 \\
\hline
\end{tabular}

(b)

\begin{tabular}{lccccr}
\hline & $d f$ & SS & MS & $F$ & Significance $F$ \\
\hline Regression 2 & 79.33350216 & 39.66675 & 93.72259708 & $7.08991 E-13$ \\
Residual & 27 & 11.4273645 & 0.423236 & & \\
\hline Total & 29 & 90.76086667 & & & \\
\hline
\end{tabular}

(c)

\begin{tabular}{lcc}
\hline & Coefficients & Standard error \\
\hline Intercept & 14.03251613 & 2.691542602 \\
$T_{\mathrm{a}}$ & 0.867171815 & 0.099396709 \\
Radiation $(G)$ & 0.004692967 & 0.00174276 \\
\hline
\end{tabular}

\section{Nomenclature}

DART: Data acquisition and real-time

cRIO: Compact reconfigurable input output

SPMS: Solar PV monitoring station

$G_{\text {ref }}: \quad$ Reference radiation value of $1000 \mathrm{~W} / \mathrm{m}^{2}$

$G_{T}: \quad$ Measured radiation value in $\mathrm{W} / \mathrm{m}^{2}$

$T_{\mathrm{a}}$ : Ambient temperature

$T_{c}: \quad$ Cell temperature

$T_{\mathrm{m}}$ : $\quad$ Module temperature

$T_{\text {array }}: \quad$ Array temperature

$\mathrm{FF}_{\mathrm{s}}$ : $\quad$ Surface temperature for fixed flat PV generator

$\mathrm{FF}_{\mathrm{b}}$ : $\quad$ Bottom-side temperature for fixed flat PV generator

$\mathrm{TF}_{\mathrm{s}}$ : $\quad$ Surface temperature for tracking flat PV generator

$\mathrm{TF}_{\mathrm{b}}$ : $\quad$ Bottom-side temperature for tracking flat PV generator

$\mathrm{CPV}_{\mathrm{s}}$ : $\quad$ Surface temperature for concentrating PV generator

$\mathrm{CPV}_{\mathrm{b}}$ : Bottom-side temperature for concentrating PV generator

SE: $\quad$ Standard error

NI: National instrument

ANOVA: Analysis of variance

MLR: Multiple linear regression

$R^{2}$ : $\quad$ Significant correlation factor

DAQ: Data acquisition

RT: $\quad$ Real time

HMI: Human machine interface.

\section{Acknowledgments}

The authors would like to thank Sichuan Zhonghan Solar Power Co. Ltd for the generous support on setting up the
PV pilot plant, assisting in data monitoring and analysis and sharing of technologies throughout the research process. Furthermore, they delegate their thanks to the Research Management Centre (RMC), Universiti Putra, Malaysia, for the approval of research funding under the Project Matching Grant (Vote no.: 9300400) and Ministry of Higher Education, Malaysia, for the approval of Fundamental Research Grant Scheme (FRGS Vote no.: 5524167).

\section{References}

[1] H. Hashim and W. S. Ho, "Renewable energy policies and initiatives for a sustainable energy future in Malaysia," Renewable and Sustainable Energy Reviews, vol. 15, no. 9, pp. 4780-4787, 2011.

[2] M. S. Ngan and C. W. Tan, "Assessment of economic viability for $\mathrm{PV} /$ wind/diesel hybrid energy system in southern Peninsular Malaysia," Renewable and Sustainable Energy Reviews, vol. 16, no. 1, pp. 634-647, 2012.

[3] M. H. Hasan, T. M. I. Mahlia, and H. Nur, "A review on energy scenario and sustainable energy in Indonesia," Renewable and Sustainable Energy Reviews, vol. 16, no. 4, pp. 2316-2328, 2012.

[4] C. Jivacate, "PV development in Thailand," Solar Energy Materials and Solar Cells, vol. 34, no. 1-4, pp. 57-66, 1994.

[5] A. Chimtavee and N. Ketjoy, "PV generator performance evaluation and load analysis of the PV microgrid system in Thailand," Procedia Engineering, vol. 32, pp. 384-391, 2012.

[6] A. Q. Malik, "Assessment of the potential of renewables for Brunei Darussalam," Renewable and Sustainable Energy Reviews, vol. 15, no. 1, pp. 427-437, 2011.

[7] W. W. Kyaw, S. Sukchai, N. Ketjoy, and S. Ladpala, "Energy utilization and the status of sustainable energy in Union of Myanmar," Energy Procedia, vol. 9, pp. 351-358, 2011.

[8] http://www.met.gov.my/.

[9] Energy Commisson of Malaysia, "Electricity supply industry in malaysia performance and statistical Information 2009," http//www.st.gov.my/.

[10] W. N. Chen, article in Malaysia Energy Guide 2010/2011, pp. $42-$ 56, entitle Solar Photovoltaic: Plug into the Sun, MBIPV Project.

[11] http://www.mbipv.net.my/.

[12] S. Ahmad, M. Z. A. A. Kadir, and S. Shafie, "Current perspective of the renewable energy development in Malaysia," Renewable and Sustainable Energy Reviews, vol. 15, no. 2, pp. 897-904, 2011.

[13] V. Quaschning, Understanding Renewable Energy Systems, Earthscan, 1st edition, 2006.

[14] R. Baños, F. Manzano-Agugliaro, F. G. Montoya, C. Gil, A. Alcayde, and J. Gómez, "Optimization methods applied to renewable and sustainable energy: a review," Renewable and Sustainable Energy Reviews, vol. 15, no. 4, pp. 1753-1766, 2011.

[15] Malaysian Standard MS IEC, "Solar Photovoltaic Energy Systems-Terms, Definitions and Symbols," 61836, 2010.

[16] M. Mattei, G. Notton, C. Cristofari, M. Muselli, and P. Poggi, "Calculation of the polycrystalline PV module temperature using a simple method of energy balance," Renewable Energy, vol. 31, no. 4, pp. 553-567, 2006.

[17] V. V. Iyengar, B. K. Nayak, and M. C. Gupta, "Silicon PV devices based on a single step for doping, anti-reflection and surface passivation," Solar Energy Materials and Solar Cells, vol. 94, no. 12, pp. 2205-2211, 2010. 
[18] B. Parida, S. Iniyan, and R. Goic, "A review of solar photovoltaic technologies," Renewable and Sustainable Energy Reviews, vol. 15, no. 3, pp. 1625-1636, 2011.

[19] E. Skoplaki and J. A. Palyvos, "On the temperature dependence of photovoltaic module electrical performance: a review of efficiency/power correlations," Solar Energy, vol. 83, no. 5, pp. 614-624, 2009.

[20] M.-J. Wu, E. J. Timpson, and S. E. Watkins, “Temperature considerations in solar arrays," in Proceedings of the IEEE Region 5 Conference: Annual Technical and Leadership Workshop, pp. 19, April 2004.

[21] A. Gastli and Y. Charabi, "Solar electricity prospects in Oman using GIS-based solar radiation maps," Renewable and Sustainable Energy Reviews, vol. 14, no. 2, pp. 790-797, 2010.

[22] T. Minemoto, H. Takahashi, Y. Nakada, and H. Takakura, "Outdoor performance evaluation of photovoltaic modules using contour plots," Current Applied Physics, vol. 10, no. 2, pp. S257-S260, 2010.

[23] S. Nagae, M. Toda, T. Minemoto, H. Takakura, and Y. Hamakawa, "Evaluation of the impact of solar spectrum and temperature variations on output power of silicon-based photovoltaic modules," Solar Energy Materials and Solar Cells, vol. 90, no. 20, pp. 3568-3575, 2006.

[24] S. Fukushige, K. Ichida, T. Minemoto, and H. Takakura, "Analysis of the temperature history of amorphous silicon photovoltaic module outdoors," Solar Energy Materials and Solar Cells, vol. 93, no. 6-7, pp. 926-931, 2009.

[25] E. Skoplaki and J. A. Palyvos, "Operating temperature of photovoltaic modules: a survey of pertinent correlations," Renewable Energy, vol. 34, no. 1, pp. 23-29, 2009.

[26] K. E. Park, G. H. Kang, H. I. Kim, G. J. Yu, and J. T. Kim, "Analysis of thermal and electrical performance of semitransparent photovoltaic (PV) module," Energy, vol. 35, no. 6, pp. 2681-2687, 2010.

[27] J. P. Kim, H. Lim, J. H. Song, Y. J. Chang, and C. H. Jeon, "Numerical analysis on the thermal characteristics of photovoltaic module with ambient temperature variation," Solar Energy Materials and Solar Cells, vol. 95, no. 1, pp. 404-407, 2011.

[28] A. Q. Jakhrani, A.-K. Othman, A. R. H. Rigit, and S. R. Samo, "Determination and comparison of different photovoltaic module temperature models for Kuching, Sarawak," in Proceedings of the IEEE 1st Conference on Clean Energy and Technology (CET '11), pp. 231-236, Kuala Lumpur, Malaysia, June 2011.

[29] J. A. Jiang, J. C. Wang, K. C. Kuo, Y. L. Su, J. C. Shieh, and J. J. Chou, "Analysis of the junction temperature and thermal characteristics of photovoltaic modules under various operation conditions," Energy, vol. 44, no. 1, pp. 292-301, 2012.

[30] R. G. Ross and M. I. Smokler, "Flat-plate solar array project final report-volume VI: engineering sciences and reliability," Report DOE/JPL, 1986.

[31] T. Schott, "Operation temperatures of PV modules," in Proceedings of the 6th E.C Photovoltaic Solar Energy Conference, pp. 392396, London, UK, 1985.

[32] J. D. Mondol, Y. G. Yohanis, and B. Norton, "Comparison of measured and predicted long term performance of grid a connected photovoltaic system," Energy Conversion and Management, vol. 48, no. 4, pp. 1065-1080, 2007.

[33] J. D. Mondol, Y. G. Yohanis, and B. Norton, “The effect of low insolation conditions and inverter oversizing on the long-term performance of a grid-connected photovoltaic system," Progress in Photovoltaics, vol. 15, no. 4, pp. 353-368, 2007. 

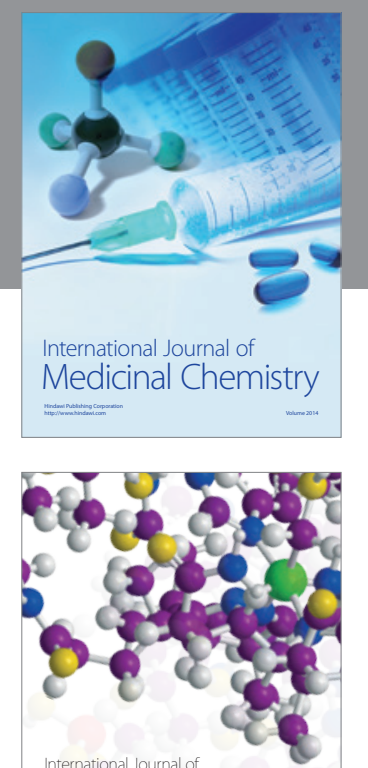

\section{Carbohydrate} Chemistry

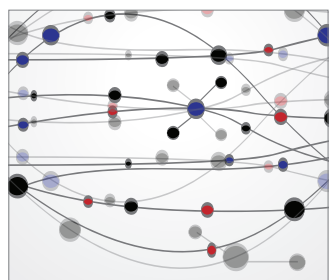

The Scientific World Journal
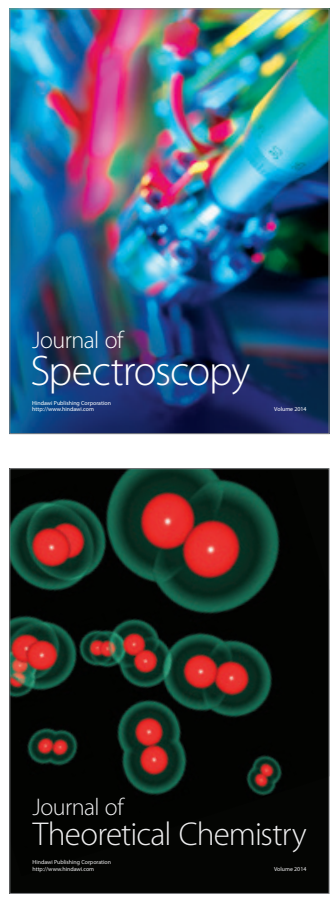
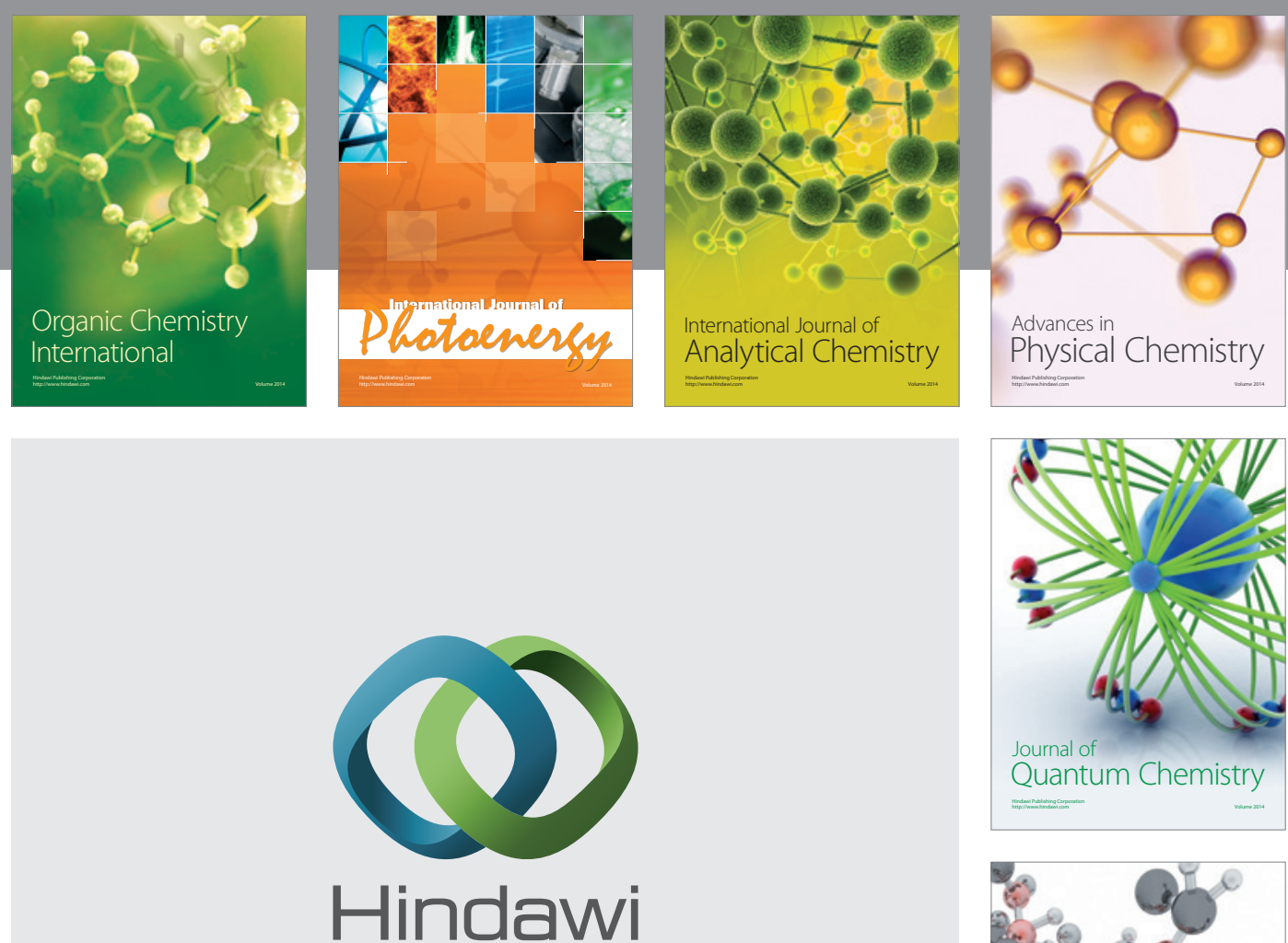

Submit your manuscripts at

http://www.hindawi.com

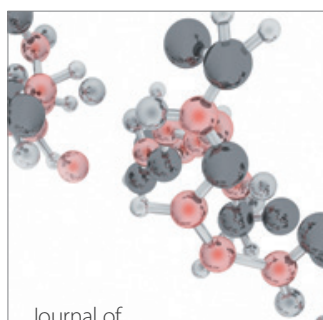

Analytical Methods

in Chemistry

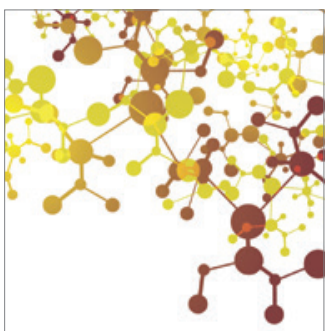

Journal of

Applied Chemistry

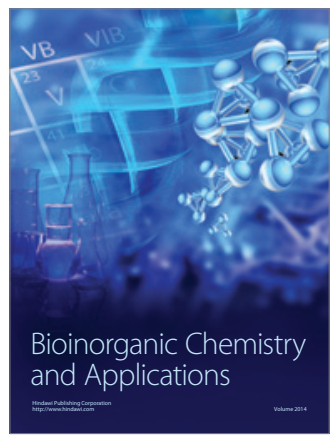

Inorganic Chemistry
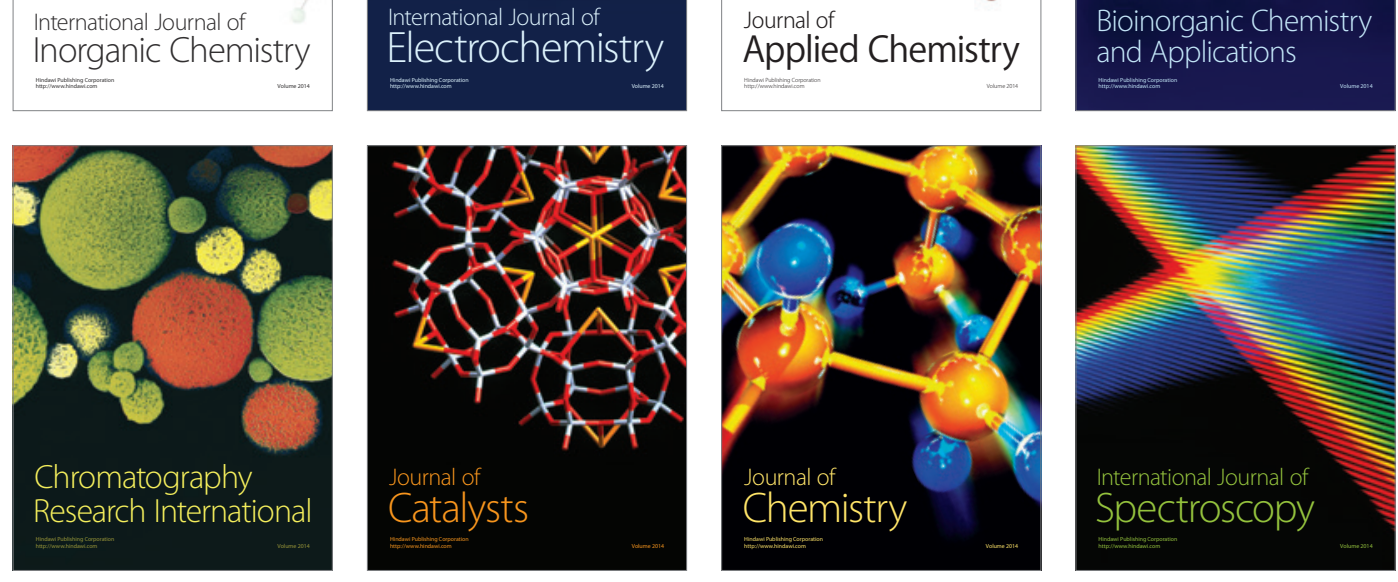